\title{
Arctic entomology in the 21st century
}

\author{
Toke T. Høye, ${ }^{1}$ Derek S. Sikes
}

\begin{abstract}
Research interest in the Arctic is accelerating because of observed and anticipated dramatic climate change and its impacts on societies and ecosystems. Arthropods form a major part of the terrestrial species diversity in the Arctic, and are particularly sensitive to changes in the abiotic environment. Hence, increased research activity on Arctic arthropods would help towards conservation of Arctic biodiversity as well as in understanding the role of Arctic arthropods in ecosystem functioning. In this introduction to the special issue on Arctic entomology in the 21st century, we identify trophic interactions, biodiversity assessments, and taxonomic revisions as three important research fields in Arctic entomology. We also point to ways in which Arctic entomology could take advantage of recent developments in other research fields and we place the contributions to the special issue in a broader context. Arthropods form ideal model organisms in global change studies and there is a particular need for entomological studies from the dramatically changing Arctic. It is our hope that the papers within this special issue will be a valuable source of inspiration and may stimulate novel insights and achievements in Arctic entomology during the 21st century.
\end{abstract}

Résumé-L'intérêt pour la recherche en Arctique s'accélère à cause des changements climatiques dramatiques observés ou anticipés, ainsi que de leurs impacts sur les sociétés et les écosystèmes. Les arthropodes forment la majeure partie de la diversité des espèces terrestres en Arctique, et sont particulièrement sensibles aux changements dans l'environnement abiotique. Ainsi, de plus fortes activités de recherche sur les arthropodes arctiques aideraient une meilleure conservation de la biodiversité arctique ainsi qu'une meilleure compréhension du rôle des arthropodes arctiques dans le fonctionnement des écosystèmes. Dans cette introduction au numéro spécial sur l'entomologie arctique au $21^{\mathrm{e}}$ siècle, nous avons identifié les interactions trophiques, l'évaluation de la biodiversité ainsi que les révisions taxonomiques comment étant trois domaines de recherche importants en entomologie arctique. Nous indiquons également des façons dont l'entomologie arctique pourrait bénéficier de récents développements dans d'autres domaines de recherche et nous plaçons les contributions à ce numéro spécial dans un contexte plus large. Les arthropodes forment des organismes modèles idéaux dans les études sur les changements globaux et il y a un besoin particulier pour des études entomologiques dans un Arctique qui change dramatiquement. Nous espérons que les articles dans ce numéro spécial constitueront une source précieuse d'inspiration et pourront stimuler de nouvelles perspectives et accomplissements dans l'entomologie arctique durant le $21^{\mathrm{e}}$ siècle.

The Arctic is currently receiving increased attention across many research fields, because of observed and anticipated dramatic climate change (Serreze and Francis 2006; Post et al. 2009). The ongoing melting of ice in the Polar Sea will have dramatic consequences for abiotic conditions in marine as well as freshwater and terrestrial environments (Post et al. 2009; Screen and Simmonds 2010; Wassmann et al. 2011).
In terrestrial environments, warming will likely lead to a deepening of the active layer and the expansion of shrubs with profound effects on the ecology and biodiversity of the Arctic (Callaghan et al. 2005). Arthropods form a major part of the terrestrial species diversity in the Arctic, and are particularly sensitive to changes in the abiotic environment (Høye et al. 2007; Høye and Forchhammer 2008b). Hence,

Received 20 December 2012. Accepted 20 December 2012.

T.T. Høye, ${ }^{1}$ Department of Bioscience, Kalø, Aarhus University, Grenåvej 14, DK-8410 Rønde, Denmark; and Arctic Research Centre, Aarhus University, C.F. Møllers Allé 8, bldg. 1110, DK-8000 Århus C, Denmark D.S. Sikes, University of Alaska Museum, 907 Yukon Drive, Fairbanks, AK 99775-6960, United States of America

${ }^{1}$ Corresponding author (e-mail: toh@dmu.dk).

doi: $10.4039 /$ tce. 2013.14 
increased knowledge about the ecology, diversity, and distributions of these animals would fill an important gap in our understanding of how to conserve Arctic biodiversity. This special issue of The Canadian Entomologist is timely in this respect because each paper adds important knowledge about Arctic arthropods and because it highlights the large scientific potential for using Arctic arthropods as models in global change studies. Here, we outline ways in which Arctic entomology could take advantage of recent developments in other research fields and place the contributions to the special issue in a broader context.

It is acknowledged that trophic interactions play an important role in ecosystem feedbacks to the climate system (Callaghan et al. 2011). In Arctic ecosystems, recent studies have demonstrated the importance of mammalian herbivores in carbon budgets (Cahoon et al. 2012). It is possible, however, that arthropod herbivores such as larvae of noctuid moths (Lepidoptera: Noctuidae) also play a similar role through periodic outbreaks, causing vegetation die-backs extending across large spatial scales in the boreal and recently also in the Arctic zone (Jepsen et al. 2008). Similarly, it has been shown from temperate ecosystems that manipulating arthropod predators can cause trophic cascades ultimately influencing plant composition (Schmitz 2006). Although Arctic arthropod food webs are more complex than previously believed, there may be limited functional redundancy among Arctic species (Hodkinson and Coulson 2004). Hence, range shifts, extirpations, or invasions of species could have stronger repercussions in Arctic food webs compared with food webs at lower latitudes with higher functional redundancy. Trophic interactions could, therefore, play an important role in affecting primary productivity and decomposition, but more research is needed on such possible biological feedbacks to the global climate cycle through effects on the large carbon stocks stored in tundra soils (Tarnocai et al. 2009).

The strong seasonality and harsh environmental conditions of the Arctic suggests that climate change will likely have particularly strong effects on arthropods there. The life cycles and phenology of Arctic arthropods are probably adapted to time resource demands with periods of high resource availability or low risk of predation or parasitism (Danks 2004). With a changing climate, such a temporal match may no longer occur if trophically linked organisms respond to different cues or at a different rate to the same cues (Miller-Rushing et al. 2010). The current pace of climate change is likely to affect species and communities to very different degrees possibly resulting in communities that are compositionally unlike any found today (Williams and Jackson 2007).

In order to meet the dual challenge of conserving Arctic arthropod biodiversity and understanding the role of arthropods in ecosystem functioning, there is an urgent need for taxonomic revisions of poorly described groups, high resolution distributional data on individual species, as well as a better understanding of the role of trophic interactions in shaping community composition and population dynamics of individual species. In this special issue of The Canadian Entomologist, experts on Arctic entomology provide examples of work being done to gauge the consequences of ongoing and future climate change in the Arctic. The papers are structured under three headings: trophic interactions in the Arctic, Arctic biodiversity, and taxonomic revisions. The background and major findings of these papers are briefly presented and placed in context of the three headings below.

\section{Trophic interactions in the Arctic}

Millions of birds migrate to Arctic breeding grounds every year. Shorebirds are dependent on energy sources on their breeding grounds for egg production and incubation (Klaassen et al. 2001; Meltofte et al. 2007). Terrestrial invertebrates and insects in particular make up the majority of their food supply on the breeding grounds and may determine local densities of breeding birds. The drivers of seasonal and interannual variation in insect biomass are therefore likely to indirectly affect both breeding densities and breeding performance of insectivorous birds in the Arctic (Meltofte et al. 2008). The paper by Bolduc et al. (2013) presents the results of trapping arthropods throughout the growing season on a near-daily basis across multiple years at four sites along a latitudinal gradient in the Canadian 
Arctic. Both near-daily and seasonal aspects of temperature were important predictors of arthropod biomass although models of arthropod families with synchronised emergence had a better fit to data.

Another prominent feature of boreal and Arctic ecosystems is the interannual variation in populations of herbivorous insects like defoliating caterpillars. Such outbreaks exhibit distinct spatial structures suggesting that trophic interactions could be regulating insect herbivore densities in some vegetation types and not in others. Schott et al. (2013) set out to test the hypothesis that moth outbreaks are the result of release from generalist arthropod predators such as harvestmen (Opiliones), spiders (Araneae), rove beetles (Coleoptera: Staphylinidae), and carabid beetles (Coleoptera: Carabidae) along altitudinal transects at two sites in northern Norway. Using a thorough multiannual sampling protocol across years with varying insect herbivore densities, they provide strong evidence against a role of generalist predators in regulating insect herbivore densities. Taken together, these two important papers illustrate the importance of space and time in the dynamics of Arctic arthropod communities, which is an understudied yet key feature of northern ecosystems.

\section{Arctic biodiversity}

Biodiversity assessments are relatively scarce for Arctic arthropods and some of the most extensive sampling efforts across multiple years have limited information about the composition of individual species (Tulp and Schekkerman 2006; Høye and Forchhammer 2008a, 2008b; McKinnon et al. 2012, but see Høye et al. 2009). Moreover, typically larger efforts to sample a broad spectrum of arthropods have relied on pitfall trapping as the sole collection technique. Sikes et al. (2013) present results of applying a range of sampling techniques for collection of spider species from the Toolik Field station on the North Slope of Alaska, United States of America. The authors report a surprisingly high diversity of this group and demonstrate that none of the sampling techniques would have yielded such richness alone. By comparing their richness estimates to a recent study from the same area using only pitfall trapping (Wyant et al. 2011), the authors argue that richness estimates of many groups of Arctic arthropods may be substantially underestimated. The study by Ernst and Buddle (2013) confirm this notion by a study of the epigeic beetle fauna at Kugluktuk, Nunavut, Canada, demonstrating not only high species richness but also high functional diversity of this group. Also, assemblages from their two sites exhibited distinct seasonal turnover in function.

Várkonyi and Roslin (2013) describe a high Arctic host-parasitoid food web in northeast Greenland based on three years of sampling with a variety of methods. Their rich description of this community provides data to test predictions such as "the species diversity of Arctic parasitoids is low". In so doing they also address the very important concern of sampling methods and their limitations. Despite the Arctic's reputation for being species poor, sufficient sampling effort using adequate sampling methods is still required to allow for robust conclusions on species richness. Using a careful assessment of the thoroughness of their methods, they conclude that the trophic interactions they described should represent $96 \%$ of those in the entire community but conclude that even at $74^{\circ} \mathrm{N}$ more species remain to be found. Overall, their effort provides an excellent baseline for future work and describes a diverse and complex and typically poorly studied community in the Arctic (Fernandez-Triana et al. 2011).

Leung and Reid (2013) compare modern to historic butterfly records for Herschel Island, Yukon, Canada, adding more critical baseline data for future studies on the impacts of climate change. Their results indicated that changes are already detectable with both additions to, and apparent losses from, the studied fauna. Butterflies are a well-studied insect group and as such, have a richer historic data set than most, making them an ideal indicator taxon for studies focussed on climate change. Leung and Reid's documentation of northward range shifts nicely complements recent reports from lower latitudes (Hickling et al. 2006; Pöyry et al. 2009).

Coulson (2013) reviews the history of terrestrial invertebrate research in the Svalbard archipelago, well known for its vertebrate fossil research, but now possibly among the best known Arctic arthropod study sites. His review describes that research on Svalbard invertebrates has been increasing in frequency and due to the relative ease of logistics could help the archipelago become a 
centre for future studies. Given that the region is experiencing recent industrialisation and climate change, Coulson's review is timely and valuable in maintaining momentum in efforts to understand the biological consequences of these changes. This suite of papers about Arctic arthropod biodiversity have increased our knowledge of the fauna considerably, and provided important baselines against which the effects of ongoing climatic changes can be evaluated.

\section{Taxonomic revisions}

George Barrowclough eloquently stated "A prerequisite to making any decisions concerning the preservation of populations, species, or higher taxa is knowledge of their existence" (p. 124, Eldredge 1992). As an example of such important baseline work, Dubatolov and Philipp (2013) have determined that a tiger moth species previously thought to be restricted to the Old World, is also found in North America and begin the work of untangling the taxonomy of a complex of closely related species. Valuable ecological studies such as those highlighted in this issue (e.g., Ernst and Buddle 2013; Várkonyi and Roslin 2013), cannot be conducted without a solid taxonomy for the target organisms. With such a taxonomic basis, the names of species correspond one-to-one to actual units of nature and tools exist to allow confident identifications. Unfortunately, the majority of Earth's species remain unknown to science (Mora et al. 2011) and of the estimated $<20 \%$ that have been named, the majority of these remain unrevised taxonomically, incompletely documented geographically, and their precise location on the evolutionary tree of life is unknown. It is taxonomic work, of which Dubatolov and Philipp (2013) is one small but important example, that is required to solve these problems and make these species accessible for ecological or other studies (Wheeler et al. 2012). We hope this work inspires continued interest in the taxonomy of Arctic arthropods as this provides the foundation for understanding arthropod ecology and evolution.

\section{Concluding remarks}

This special issue of The Canadian Entomologist provides many examples of how our knowledge of Arctic entomology is still relatively limited. In light of the dramatic changes expected for this region in the 21st century, further advances in this field will be of great importance for northern societies. Although conditions for performing baseline studies are constrained by competition for funding, there is still a need for descriptive studies of arthropod communities. Such studies are the prerequisite for framing more general hypotheses: for example, about the role of arthropods in ecosystem functioning and stability. It is also clear from many of the studies of this issue that the conception of the Arctic as a species poor and simple ecosystem needs revision. It will be an important future achievement to assess the functional redundancy of different compartments of the arthropod food web in order to determine the relationship between biodiversity and ecosystem functioning.

Although the future scientific challenges are many, new tools and interdisciplinary collaborations are emerging. Barcoding libraries are growing rapidly (http://ibol.org), tools to infer species composition directly from soil (eDNA) are constantly being refined (Yoccoz 2012), and there is much potential for next-generation sequencing (Hajibabaei et al. 2011). Such tools could revolutionise future species inventories, long-term monitoring, and food web studies on arthropods in the Arctic and elsewhere. However, these tools first require sound ecology and taxonomy, including examples from the papers within this special issue. Also, web-based citizen science tools and smart phone applications for recording observations of species in the field are being developed and could provide a rapid increase in observational records for charismatic species like butterflies from remote areas like most of the Arctic (e.g., http://ebutterfly. ca). Finally, international collaborations among natural history museums (e.g., SYNTHESYS an European Union-funded network of natural history museums, http://www.synthesys.info), field stations (e.g., INTERACT an European Unionfunded network of field stations, http://www.euinteract.org), and stakeholder networks (e.g., the Circumpolar Biodiversity Monitoring Program [CBMP], http://caff.is/monitoring) are also facilitating easier access to databases, sites, and networks and provide new opportunities for entomological research in the Arctic. 
In sum, although the Arctic will be facing immense pressures in the future, we remain optimistic that high-quality science can help guide sustainable interactions between humans and the natural resources of the Arctic. Arthropods form ideal model organisms in global change studies because of their sensitivity to environmental change and there is a particular need for such studies from the dramatically changing Arctic. It is our hope that the papers within this special issue will be a valuable source of inspiration and may stimulate novel insights and achievements in Arctic entomology during the 21 st century.

\section{Acknowledgements}

The authors sincerely thank the Editor-in-Chief of The Canadian Entomologist, Christopher M. Buddle, for taking the initiative on the production of this special issue on Arctic entomology in the 21 st century and editorial assistant Andrew Smith for help and support during the editorial process.

\section{References}

Bolduc, E., Casajus, N., Legagneux, P., McKinnon, L., Gilchrist, H.G., Leung, M., et al. 2013. Terrestrial arthropod abundance and phenology in the Canadian Arctic: modelling resource availability for Arctic-nesting insectivorous birds. The Canadian Entomologist, 145: 155-170.

Cahoon, S.M.P., Sullivan, P.F., Post, E., and Welker, J.M. 2012. Large herbivores limit $\mathrm{CO}_{2}$ uptake and suppress carbon cycle responses to warming in West Greenland. Global Change Biology, 18: 469-479. doi:10.1111/j.1365-2486.2011.02528.x.

Callaghan, T.V., Chapin, III, F.S., Chernov, Y., Christensen, T.R., Huntley, B., Ims, R.A., et al. 2005. Arctic tundra and polar desert ecosystems. In Arctic climate impact assessment. Edited by C. Symon, L. Arris, and B. Heal. Cambridge University Press, New York, United States of America. Pp. 243-352.

Callaghan, T.V., Johansson, M., Key, J., Prowse, T., Ananicheva, M., and Klepikov, A. 2011. Feedbacks and interactions: from the Arctic cryosphere to the climate system. Ambio, 40: 75-86. doi:10.1007/ s13280-011-0215-8.

Coulson, S.J. 2013. The terrestrial invertebrate fauna of the Svalbard archipelago in a changing world: history of research and challenges. The Canadian Entomologist, 145: 131-146.

Danks, H.V. 2004. Seasonal adaptations in Arctic insects. Integrative and Comparative Biology, 44: 85-94.
Dubatolov, V.V. and Philipp, K.W. 2013. Review of the northern Holarctic Arctia caja complex (Lepidoptera: Noctuidae: Arctiinae). The Canadian Entomologist, 145: 147-154.

Eldredge, N. 1992. Systematics, ecology, and the biodiversity crisis. Columbia University Press, New York, United States of America.

Ernst, C.M. and Buddle, C.M. 2013. Seasonal patterns in the structure of epigeic beetle (Coleoptera) assemblages in two subarctic habitats in Nunavut, Canada. The Canadian Entomologist, 145: 171-183.

Fernandez-Triana, J., Smith, M.A., Boudreault, C., Goulet, H., Hebert, P.D.N., Smith, A.C., et al. 2011. A poorly known high-latitude parasitoid wasp community: unexpected diversity and dramatic changes through time. Plos One, 6: ARTN e23719. doi:10.1371/journal.pone.0023719.

Hajibabaei, M., Shokralla, S., Zhou, X., Singer, G.A.C., and Baird, D.J. 2011. Environmental barcoding: a next-generation sequencing approach for biomonitoring applications using river benthos. Plos One, 6: e17497. doi:10.1371/journal. pone.0017497.

Hickling, R., Roy, D.B., Hill, J.K., Fox, R., and Thomas, C.D. 2006. The distributions of a wide range of taxonomic groups are expanding polewards. Global Change Biology, 12: 450-455. doi:10.1111/j.1365-2486.2006.01116.x.

Hodkinson, I.D. and Coulson, S.J. 2004. Are high Arctic terrestrial food chains really that simple? - The Bear Island food web revisited. Oikos, 106: 427-431.

Høye, T.T. and Forchhammer, M.C. 2008a. The influence of weather conditions on the activity of high-arctic arthropods inferred from long-term observations. BMC Ecology, 8: 8. doi:10.1186/ 1472-6785-8-8

Høye, T.T. and Forchhammer, M.C. $2008 \mathrm{~b}$. Phenology of high-arctic arthropods: effects of climate on spatial, seasonal and inter-annual variation. Advances in Ecological Research, 40: 299-324.

Høye, T.T., Hammel, J.U., Fuchs, T., and Toft, S. 2009. Climate change and sexual size dimorphism in an arctic spider. Biology Letters, 5: 542-544.

Høye, T.T., Post, E., Meltofte, H., Schmidt, N.M., and Forchhammer, M.C. 2007. Rapid advancement of spring in the high Arctic. Current Biology, 17: R449-R451.

Jepsen, J.U., Hagen, S.B., Ims, R.A., and Yoccoz, N.G. 2008. Climate change and outbreaks of the geometrids Operophtera brumata and Epirrita autumnata in subarctic birch forest: evidence of a recent outbreak range expansion. Journal of Animal Ecology, 77: 257-264. doi:10.1111/j.1365-2656. 2007.01339.x.

Klaassen, M., Lindstrom, A., Meltofte, H., and Piersma, T. 2001. Arctic waders are not capital breeders. Nature, 413: 794-794. 
Leung, M.C. and Reid, D.G. 2013. New species records for butterflies (Lepidoptera) on Herschel Island, Yukon, Canada, with notes on natural history. The Canadian Entomologist, 145: 227-234.

McKinnon, L., Picotin, M., Bolduc, E., Juillet, C., and Bety, J. 2012. Timing of breeding, peak food availability, and effects of mismatch on chick growth in birds nesting in the high Arctic. Canadian Journal of Zoology (Revue Canadienne De Zoologie), 90: 961-971. doi:10.1139/z2012-064.

Meltofte, H., Høye, T.T., and Schmidt, N.M. 2008. Effects of food availability, snow and predation on breeding performance of waders at Zackenberg. Advances in Ecological Research, 40: 325-343.

Meltofte, H., Høye, T.T., Schmidt, N.M., and Forchhammer, M.C. 2007. Differences in food abundance cause inter-annual variation in the breeding phenology of high Arctic waders. Polar Biology, 30: 601-606.

Miller-Rushing, A.J., Høye, T.T., Inouye, D.W., and Post, E. 2010. The effects of phenological mismatches on demography. Philosophical Transactions of the Royal Society of London B, 365: 3177-3186.

Mora, C., Tittensor, D.P., Adl, S., Simpson, A.G.B., and Worm, B. 2011. How many species are there on Earth and in the ocean? PLoS Biology, 9: e1001127. doi:10.1371/journal.pbio.1001127.

Post, E., Forchhammer, M.C., Bret-Harte, M.S., Callaghan, T.V., Christensen, T.R., Elberling, B., et al. 2009. Ecological dynamics across the Arctic associated with recent climate change. Science, 325: $1355-1358$.

Pöyry, J., Luoto, M., Heikkinen, R.K., Kuussaari, M., and Saarinen, K. 2009. Species traits explain recent range shifts of Finnish butterflies. Global Change Biology, 15: 732-743. doi:10.1111/j.1365-2486. 2008.01789.x.

Schmitz, O.J. 2006. Predators have large effects on ecosystem properties by changing plant diversity, not plant biomass. Ecology, 87: 1432-1437. doi:10.1890/0012-9658(2006)87[1432:phleoe]2.0. co;2.

Schott, T., Kapari, L., Hagen, S.B., Vindstad, O.P.L., Jepsen, J.U., and Ims, R.A. 2013. Predator release from invertebrate generalists does not explain geometrid moth (Lepidoptera: Geometridae) outbreaks at high altitudes. The Canadian Entomologist, 145: 184-192.
Screen, J.A. and Simmonds, I. 2010. The central role of diminishing sea ice in recent Arctic temperature amplification. Nature, 464: 1334-1337. doi:10.1038/ nature09051.

Serreze, M.C. and Francis, J.A. 2006. The Arctic amplification debate. Climatic Change, 76: 241-264. doi:10.1007/s10584-005-9017-y.

Sikes, D.S., Draney, M.L., and Fleshman, B. 2013. Unexpectedly high among-habitat spider (Araneae) faunal diversity from the Arctic LongTerm Experimental Research (LTER) field station at Toolik Lake, Alaska, United States of America. The Canadian Entomologist, 145: 219-226.

Tarnocai, C., Canadell, J.G., Schuur, E.A.G., Kuhry, P., Mazhitova, G., and Zimov, S. 2009. Soil organic carbon pools in the northern circumpolar permafrost region. Global Biogeochemical Cycles, 23: GB2023. doi:10.1029/2008gb003327.

Tulp, I. and Schekkerman, H. 2006. Has prey availability for arctic birds advanced with climate change? Hindcasting the abundance of tundra arthropods using weather and seasonal variation. Arctic, 61: 48-60.

Várkonyi, G. and Roslin, T. 2013. Freezing cold yet diverse: dissecting a high-Arctic parasitoid community associated with Lepidoptera hosts. The Canadian Entomologist, 145: 193-218.

Wassmann, P., Duarte, C.M., Agusti, S., and Sejr, M.K. 2011. Footprints of climate change in the Arctic marine ecosystem. Global Change Biology, 17: 1235-1249. doi:10.1111/j.1365-2486. 2010.02311.x.

Wheeler, Q.D., Knapp, S., Stevenson, D.W., Stevenson, J., Blum, S.D., Boom, B.M., et al. 2012. Mapping the biosphere: exploring species to understand the origin, organization and sustainability of biodiversity. Systematics and Biodiversity, 10: 1-20. doi:10.1080/14772000.2012.665095.

Williams, J.W. and Jackson, S.T. 2007. Novel climates, no-analog communities, and ecological surprises. Frontiers in Ecology and the Environment, 5: 475-482. doi:10.1890/070037.

Wyant, K.A., Draney, M.L., and Moore, J.C. 2011. Epigeal spider (Araneae) communities in moist acidic and dry heath tundra at Toolik lake, Alaska. Arctic, Antarctic, and Alpine Research, 43: 301-312. doi:10.1657/1938-4246-43.2.301.

Yoccoz, N.G. 2012. The future of environmental DNA in ecology. Molecular Ecology, 21: 2031-2038. doi:10.1111/j.1365-294X.2012.05505.x. 